$20 \%$ off these prices if you mention HTR in your order! FOR MACINTOSH ${ }^{\circledR}$ OR WINDOWS ${ }^{\circledR}$ :

\title{
LaserHebrew $^{\circledast}$ in Unicode $^{\mathrm{TM}} \mathbf{\$ 9 9 . 9 5}$
}

Right to left with proper line wrap, full justification, automatic positioning of vowel points \& accents in Word XP-2010 or on Mac in Mellel (\$25)

NewJerusalemu:

BHS in Unicode-12 Formats \$99.95-1 form. \$59.95 LaserHebrew Converter - ASCII to Unicode $\$ \mathbf{\$ 7 9 . 9 5}$ LaserGreek $^{\circledast}$ in Unicode $\$ 99.95$ first, $\$ 50$ add.

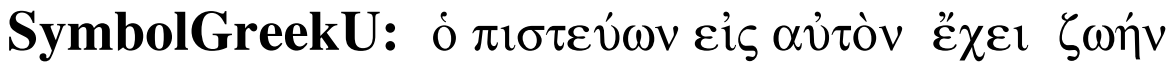

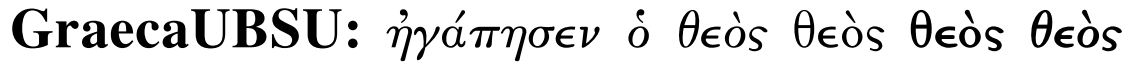

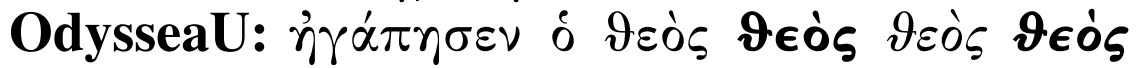

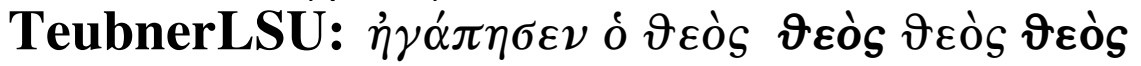

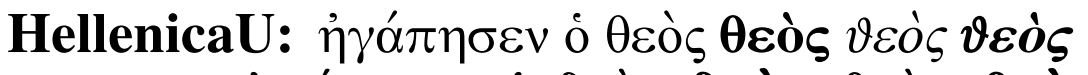

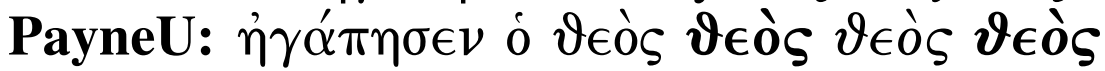
UncialLSU • GraecaU • GreekSansLSU • all 10 - \$249.95 NT MSS in Unicode Fonts - each \$49.95 - All 11 \$249.95 B: ENAPXH N: ENAPXH P46: ENAPXM W: ENAPXH NT or LXX for NT MSS in Unicode Fonts - each $\$ \mathbf{5 9 . 9 5}$ Greek NT or LXX in Unicode $\$ 59.95$ (Tagged, call) LaserGreek Converter - ASCII to/from Unicode $\mathbf{\$ 7 9 . 9 5}$ LaserCoptic $^{\circledR} \$ \mathbf{9 9 . 9 5}$ Unicode or ASCII nexe $\overline{\mathrm{IC}} \times \mathrm{Q}$ : Semitic Transliterator ${ }^{\circledR}$ - Unicode or ASCII $\$ 99.95$ 1:1 běrē'šit bārā' 'ělōhîm 'ēt haššāmayim wěeèt hā'āreș. TransIndic Transliterator ${ }^{\circledR}$ - Unicode or ASCII $\$ 99.95$

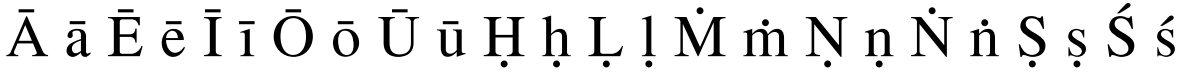

LINGUIST'S SOFTWARE, Tel: (425) 775-1130 • Fax: (425) 771-5911

Web: www.linguistsoftware.com•E-mail: sales@linguistsoftware.com 


\section{Harvard Theological Review}

108:1

JANUARY 2015

\section{ARTICLES}

Comparative Theology as Repeating with a Difference:

Deconstruction, Yogācāra Buddhism, and Our Conditioned

Condition

Kristin Beise Kiblinger

Paul's Ethnic Discourse on "Faith": Christ's Faithfulness

and Gentile Access to the Judean God in Romans 3:21-5:1

Stephen L. Young

Luther on Necessity

Knut Alfsvåg

Divine Concessions in the Tanhuma Midrashim

Dov Weiss

Dialect of the Tribe: Modes of Communication and the Epiphanic

Role of Nonhuman Imagery in T. S. Eliot's Four Quartets

William Kevin Penny

"A Heart of Many Chambers": The Theological Hermeneutics

of Legal Multivocality

Steve Fraade

Eusebius as Political Theologian: The Legend Continues

Devin Singh

Irreducible Reality, Irreducible Persons

Brent Waters

Books Received

Index 